\title{
A Novel Cell Therapy Method for Recovering after Brain Stroke in Rats
}

\author{
Seyed Mojtaba Hosseini ${ }^{1,2,3}$, Mohammad Farahmandnia, ${ }^{1,2}$, Sepehr Kazemi ${ }^{1,2}$, \\ Benafshe Shakibajahromi ${ }^{1,2}$, Fatemeh Sabet Sarvestani ${ }^{1,2}$, Zahra Khodabande ${ }^{4}$ \\ ${ }^{1}$ Student Research Committee, ${ }^{2}$ Cell $\mathcal{E}$ Molecular Medicine Student Research Group, Medical School, ${ }^{3}$ Stem Cell Laboratory, \\ Department of Anatomy, ${ }^{4}$ Trangenic Technology Research Center, Shiraz University of Medical Sciences, Shiraz, Iran
}

Background: Nowadays, stroke leads to a significant part of the adult mortality and morbidity and also it could result in some neurological deficits in the patients' lives. Cell therapy has opened a new approach to treat the brain ischemia and reduce its terrible effects on the patients' lives. There are several articles which show that the cell therapy could be beneficial for treating brain stroke. In this study, we have planned to present a new cell therapy method for stroke by administration of Mesenchymal stem cells and differentiated neural stem cells without astrocytes.

Method and Materials: The Mesenchymal stem cells were isolated from tibia and femur of a 250 300 g rat and they were cultured in DMEM/F12, 10\% fetal bovine serum, 1\% Pen/Strep. Neural stem cells were isolated from 14 days rat embryo ganglion eminence and were cultured in NSA media containing Neurobasal, $\%$ B27, bFGF $10 \mathrm{ng} / \mathrm{ml}$ and EGF $20 \mathrm{ng} / \mathrm{ml}$ after 5 days they formed some neurospheres. The isolated neural stem cells were differentiated to neural lineages by adding $5 \%$ fetal bovine serum to their culture media. After 48 hours the astrocytes were depleted by using MACS kit.

Results: The group that received Mesenchymal stem cells systemically and differentiated neural stem cells without astrocytes had the best neurological outcomes and the least infarct volume and apoptosis. It could be understood that this cell therapy method might cause almost full recovery after brain stoke.

Conclusion: Using combination cell therapy with Mesenchymal stem cells and differentiated neural stem cells with removed astrocyte could provide a novel method for curing brain stroke.

Keywords: Neural stem cells, Mesenchymal stem cells, Brain stroke, Astrocyte

\section{Introduction}

Stroke is the second most important cause of death in industrial countries and the most significant cause of adult disability around the world $(1,2)$. Neurological defi-

Accepted for publication May 29, 2015, Published online November 30, 2015 Correspondence to Seyed Mojtaba Hosseini

Student Research Committee, Zand Blvd, Shiraz 7174776179, Iran Tel: +989178033070, Fax: +987132122970

E-mail: hoseini2010m@gmail.com

(c) This is an open-access article distributed under the terms of the Creative Commons Attribution Non-Commercial License (http://creativecommons.org/ licenses/by-nc/4.0/), which permits unrestricted non-commercial use, distribution, and reproduction in any medium, provided the original work is properly cited. cits contain paralysis, memory impairment, parestheisa, slurred speech; etc (3). stroke is a result of an artery occlusion that leads to lack of oxygen and glucose, this nutrient shortage could cause some irreversible damage in brain tissue (4). Inflammation caused by loss of blood perfusion plays an important role in stroke pathophysiology, secreting of some cytokines such as interleukinl (IL-1), Tumor necrosis factor- $\alpha$ (TNF- $\alpha$ ), interleukin-6 (IL-6), Transforming growth factor- $\beta$ (TGB- $\beta$ ) is resulting the post stoke inflammation $(5,6)$. Neuronal loss and brain damage is the secondary brain damage which the first neural loss is because of diminishing blood perfusion (7). the inflammatory cytokines could be secreted from microglia or astrocytes (8). Matrix metalloproteinases are a type of pro- 
teolytic enzyme that could make remodeling after stroke and is secreted by microglia, astrocyte, etc (9).

These days, there is only one approved drug for stroke which is rt-PA, it could be efficient according to thrombolytic effects; however, it has some side effects such as increasing the risk of bleeding and golden time limitation (10). Several hypotheses around mesenchymal stem cell therapy for stroke to account for therapeutic effects of this method have been suggested containing reducing inflammation, increasing angiogenesis, etc (11). This type of stem cells could be beneficial for reducing the inflammation and preparing the microenvironment by secreting some nutrients cytokines such as basic fibroblast growth factor (bFGF) and vascular endothelial growth factor (VEGF) (12). Neural stem cells is another type of stem cells which has been shown a promising approach to treat stroke and they are capable of differentiating to three neural lineage including neurons, astrocytes and oligodendrocytes (13).

In this study we have planned to transplant Mesenchymal stem cells systemically in acute phase (12 hours after ischemia) for modulating the immune system and differentiated neural stem cells with astrocyte depletion transplantation 3 days after brain ischemia for promoting neural regeneration.

\section{Materials and Methods}

\section{Animal preparation}

Seventy five Sprague Dawley male rats weighting 250 $300 \mathrm{~g}$ were selected randomly and they were divided in 7 groups $(\mathrm{n}=15)$ as below:

Control group: Control group which received no intervention and treatment

Sham group: Sham group which were underwent middle cerebral Artery occlusion (MCAO) operation without any treatment

Third Group: The group which received systemic Mesenchymal stem cells injection 12 hours after inducing $\mathrm{MCAO}$

Forth Group: The group which received differentiated neural stem cells without astrocytes intraventicular injection 3 days after inducing MCAO

Fifth Group: The group which received differentiation neural stem cells (Neurons, Oligodendrocytes and astrocytes) intraventricular injection 3 days after inducing MCAO

Sixth Group: The group which received systemic Mesenchymal stem cells 12 hours and differentiated neural stem cells (including astrocytes) after 3 days of inducing
MCAO

Seventh Group: The group which received systemic Mesenchymal stem cells 12 hours and differentiated neural stem cells without astrocytes after 3 days of inducing MCAO

The animals were kept with free access to food and water and all procedures were approved by Shiraz University of Medical Sciences ethical committee.

\section{Mesenchymal Stem Cell Isolation, Expansion and characterization}

The Mesenchymal stem cells were obtained from adult male rat femur and tibia. Briefly, the femur and tibia were isolated and the connective tissue was removed, after that the bones were flashed by Mesenchymal stem cells culture media (DMEM/F12, 10\% fetal bovine serum, 1\% Pen/Strep) and the culture media containing rat bone marrow was transferred to $\mathrm{T}-25 \mathrm{~cm}^{2}$ and incubated in $5 \% \mathrm{CO}_{2}$ and $37^{\circ} \mathrm{C}$. The media was changed every 2 days and after 7 days the flask was $80 \sim 90 \%$ confluent. The cultured cells were passaged by adding trypsin $0.05 \%$ and complete culture media.

Some Mesenchymal stem cells markers containing CD44 (CBL1508FMillipore), CD45 (05-1410 Millipore), CD90 (CBL1500F Millipore) and CD34 (ab192547Abcam) were assessed by immunocytochemistry method for the isolated cells.

The Mesenchymal stem cells (1000000 Cells/kg) were injected via tail vein 12 hours after inducing MCAO.

\section{Mesenchymal stem cells Differentiation}

To evaluate the multipotent features of the isolated cells before laser treatment, BMSCs were cultured inadipogenic and osteogenic differentiation medium (Miltenyi biotech) for approximately 21 days. The cells stained with Alizarin Red for osteogenic differentiation and Oil red for adipogenic differentiation.

\section{Neural Stem Cell Isolation, expansion and characterization}

The neural stem cells were isolated by dissecting rat embryo 14 ganglion eminences and adding neural stem cell culture media (Neurobasal, 2\% B27, bFGF 10 ng/ml, EGF $20 \mathrm{ng} / \mathrm{ml}$ and $1 \%$ pen/strep). After 5 days some spheres had formed in the culture flask which called neurospheres.

The spheres were trypsinized and the single cells were cultured in a Poly-l-lysin coated plate and 5\% fetal bovine serum was added to the neural stem cells culture media to differentiate the NSCs to three neural lineages. The neural stem cells were differentiated to neurons, oligodendrocytes and astrocytes 3 days later. The neurons and as- 
trocytes were stained with $\beta$-tubulin and GFAP by immunocytochemistry method.

For preparing the differentiated neural stem cells for injecting the astrocyte were depleted with Astrocyte sorting kit (Miltenyi biotech, cat number: 130-096-052) and their depletion was assessed with flow cytometry method.

The differentiated neural stem cells minus astrocytes were transplanted stereotactically into lateral ventricle 3 days after MCAO.

\section{Stereotactic Injection of Neural Stem Cells}

The animals were anesthetized with halothane (induction $5 \%$ and maintenance $1 \%$ ) and fixed to the stereotactical frame, the differentiated neural stem cells minus astrocytes were injected into right lateral ventricle at: Anterioposterior $(\mathrm{AP})=-0.12 \mathrm{~mm}$, mediolateral $(\mathrm{ML})=1.6 \mathrm{~mm}$, dorsoventricular $(\mathrm{DV})=4.3 \mathrm{~mm}$. Each rat received 200,000 cells in its right lateral ventricle.

\section{Middle Cerebral Artery Occlusion (MCAO)}

The rats were anesthetized by halothane $(5 \%$ induction and $1.5 \%$ for maintenance) in the mixture of $\mathrm{NO}_{2}$ and $\mathrm{O}_{2}$ (50:50). MCAO induction was performed regarding to Koizumi's method. Briefly, an incision was excised in the midline of the neck and the connective tissues, muscles and salivary glands were dissected till the carotid sheath was exposed, the sheath was removed and exposed carotid artery was separated from vagus nerve, then 2 loose sutures were prepared in common carotid artery and the external carotid artery was clamped, after that a small incision was excised between the sutures on common carotid artery and a silicon coated 4.0 nylon with round tip was passed through the common carotid artery to induce the occlusion of middle cerebral artery, after 45 minutes the 4.0 Nylon was removed and the sutures were tighten up and also the clamp on external carotid artery was opened to maintain the brain blood perfusion after the operation $(14,15)$.

\section{Neurological Function Assessment}

Neurological function was assessed every two days for all rats during 28 days of experiment. The neurological examination was scored on six-score scale. The scores are following as below (16):

Score of 0: No neurological deficit

Score of 1: Failure to extend left forepaw completely. It shows mild focal neurological deficit

Score of 2: Circling to the left. It means a moderate focal neurological deficit

Score of 3: Falling to the left. It indicates a sever focal neurological deficit

Score of 4: Not walking spontaneously and decreasing level of consciousness.

Score of 5: Death due to brain ischemia

\section{Histology}

After 28 days, the rats were anesthetized with Halothane and were fixed with normal saline followed Paraformaldehyde $4 \%$, cry sections $(20 \mu \mathrm{m})$ were mounted on silicon coated slides and stained with Hematoxin \& Eosin.

\section{Apoptosis evaluation with measurement of Caspase 3 activity}

Activation of ICE family proteases/caspases begins apoptosis in mammalian cells. This assay is based on spectrophtorometric evaluation of chromophore p-nitroaniline ( $p$-NA) after cleavage from labeled substrate DEVD- $p$-NA. The $p$-NA light emission could be measured by using spectrophotometer at $400 \sim 405 \mathrm{~nm}$. For this assay Caspase 3 assay kit from abcam company used (ab39401).

\section{Statistical Analysis}

All the data were analyzed with One-way ANOVA method with Prism 6.00 software.

\section{Results}

\section{Mesenchymal stem cells morphology and marker assessment}

The isolated rat bone marrow Mesenchymal stem cells formed few thin and long cell processes and a large nucleus in their cell body could be observed (Fig. 1). These

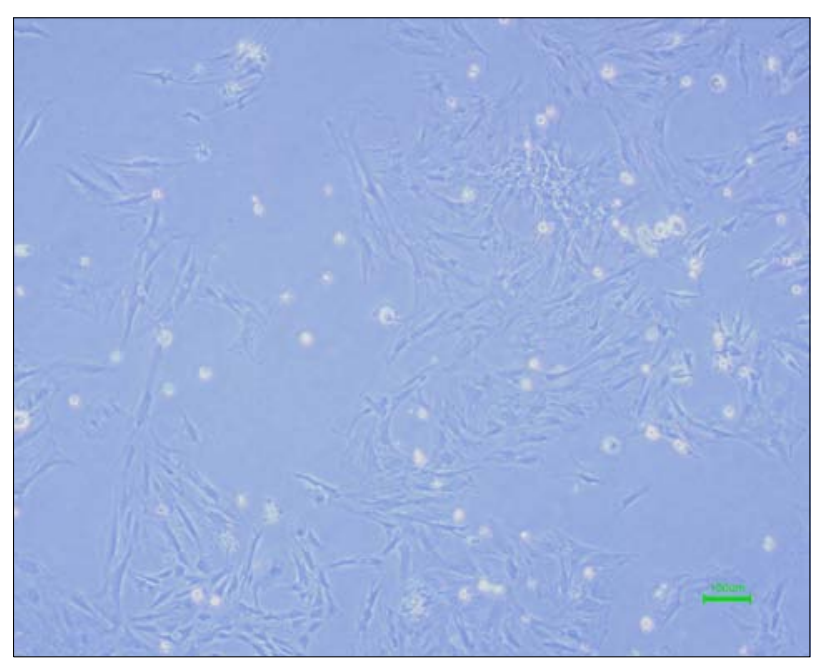

Fig. 1. Rat Mesenchymal stem cells. 
cells did not express hematopoietic stem cells markers (CD34 and CD45) and also they expressed the mesenchymal stem cells markers (CD44 and CD90) (Fig. 2, Table 1).

\section{Differentiation Assay}

Differentiation to adipocyte was confirmed by morphological changes after 7 days such as vacuole production and Oil red staining after 21 days seeding in adipogenic media.

Osteogenic differentiation was started with matrix deposition after 5 7 days and was confirmed with Alizarin Red staining after 14 days (Fig. 3).

\section{Neural Stem Cells Characterization and Differentiation}

Five days after culturing neural stem cells, some spheres formed in culture flasks which were called neurospheres

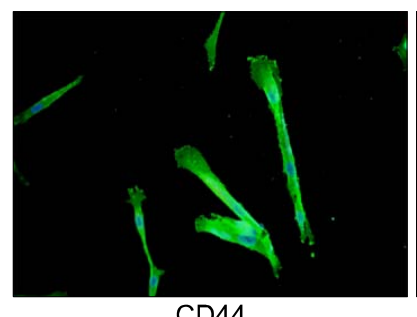

CD44

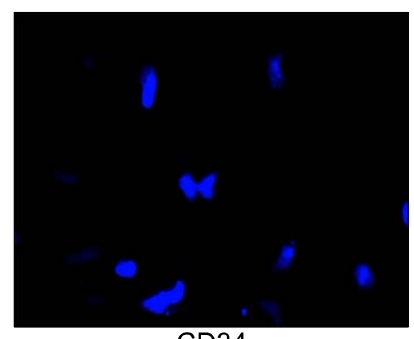

CD34

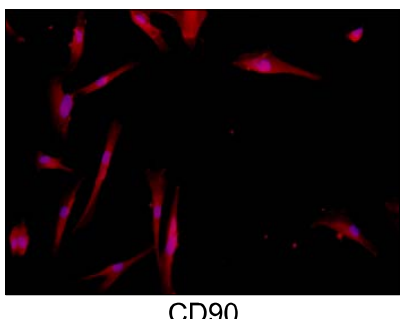

CD90

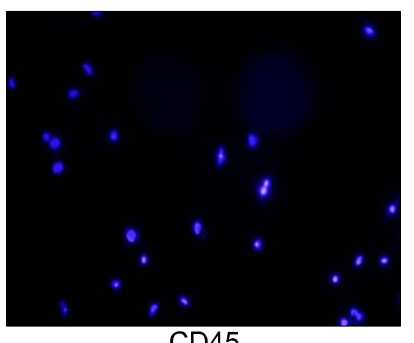

CD45
Fig. 2. Rat Mesenchymal stem cell immunocytochemistry for CD44, CD90, CD45 and CD34.
(Fig. 4). 48 hours after adding fetal bovine serum to the neural stem cells media they have differentiated to three neural lineages cell (Neurons, Oligodendrocytes and Astrocytes) as it could be seen in Fig. 5 the differentiated neural stem cells have different morphology due to different provided cell types (Fig. 5).

For evaluation of neural and astrocytes differentiation they were stained with anti $\beta$-tubulin III and anti-GFAP by immunocytochemistry method (Fig. 6, Table 2).

The astrocyte depletion of differentiated neural stem cells was assessed by flowcytometry method (Fig. 7).

\section{Neurological Examination}

All seventy five rats were examined according to six-score scale by double blind examiner every two days during 28 days of experiment. The neurological scores were analyzed with SPSS 16.00 one-way ANOVA test and there is a significant difference between the groups which received cell therapy and the sham group. In addition, the group which received Mesenchymal stem cells and differentiated neural stem cells without astrocytes had the best neurological outcome between the groups received cell therapy with $\mathrm{p}$ value less than 0.05 ( $\mathrm{p}$ value $<0.05$ ) (Fig. 8).

\section{Histology}

The coronal sections were selected with $1.2 \mathrm{~mm}$ interval and from the first one was $1 \mathrm{~mm}$ posterior to frontal pole. Damaged area was defined by some ischemic signs such as eosinophilic cytoplasm and pyknotic nuclei. The ischemic zones in the groups which were taken cell therapy

Table 1. Mesenchymal stem cells markers expression

\begin{tabular}{cccc}
\hline CD44 & CD90 & CD 34 & CD45 \\
\hline $94.44 \% \pm 2.91$ & $84.25 \% \pm 7.10$ & $1.70 \% \pm 0.84$ & $0.94 \% \pm 0.64$ \\
\hline
\end{tabular}

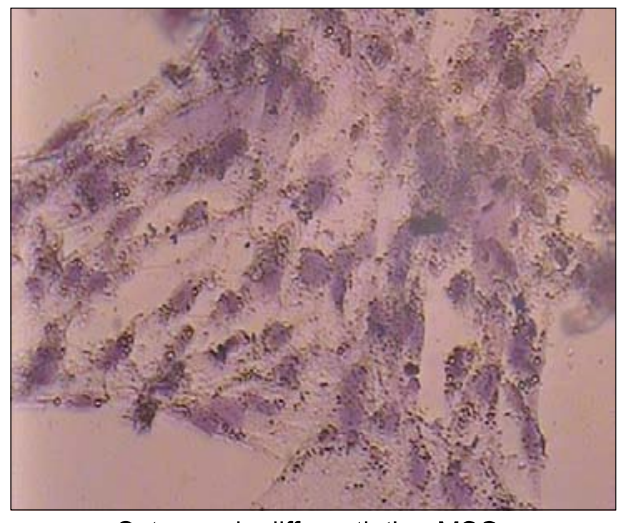

Osteogenic differentiation MSCs

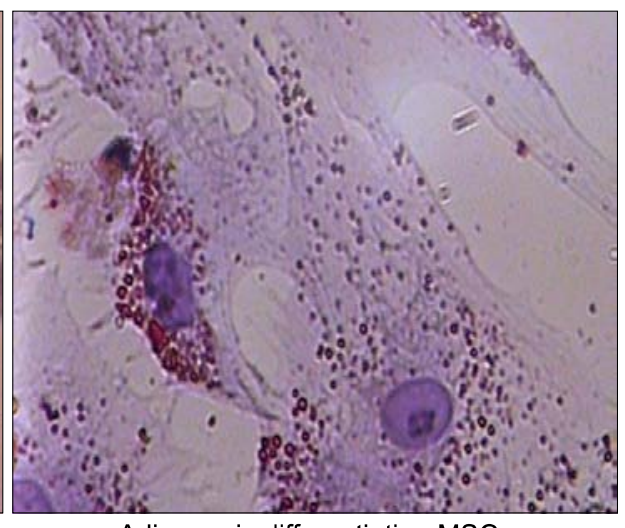

Adipogenic differentiation MSCs
Fig. 3. Mesenchymal stem cells differentiation to adipocyte and osteocyte. 


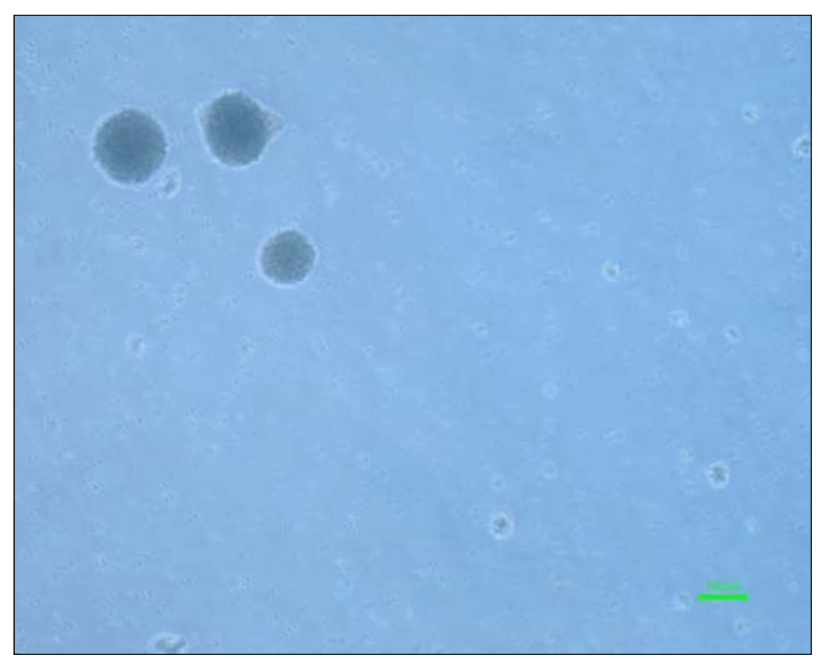

Fig. 4. Neurospheres 5 days after neural stem cell culture.

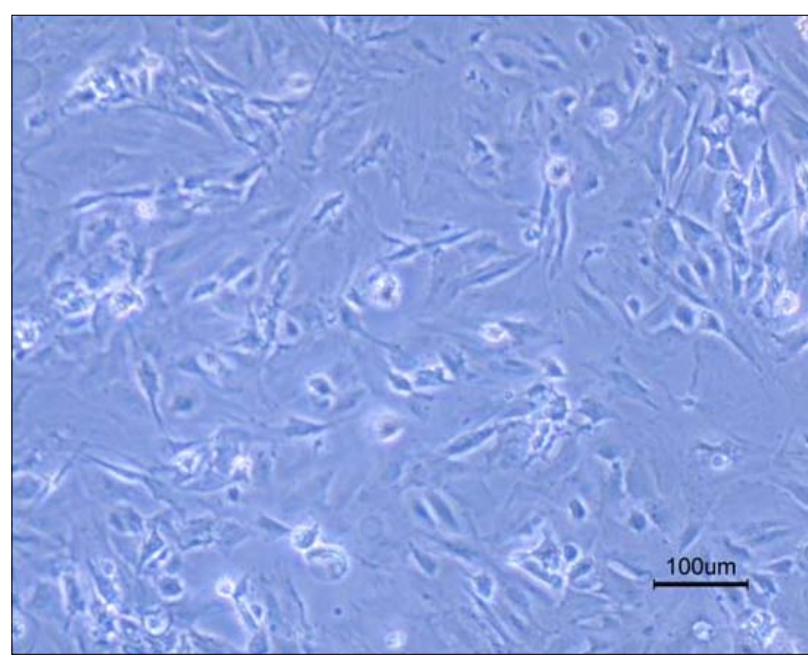

Fig. 5. Differentiated neural stem cells.

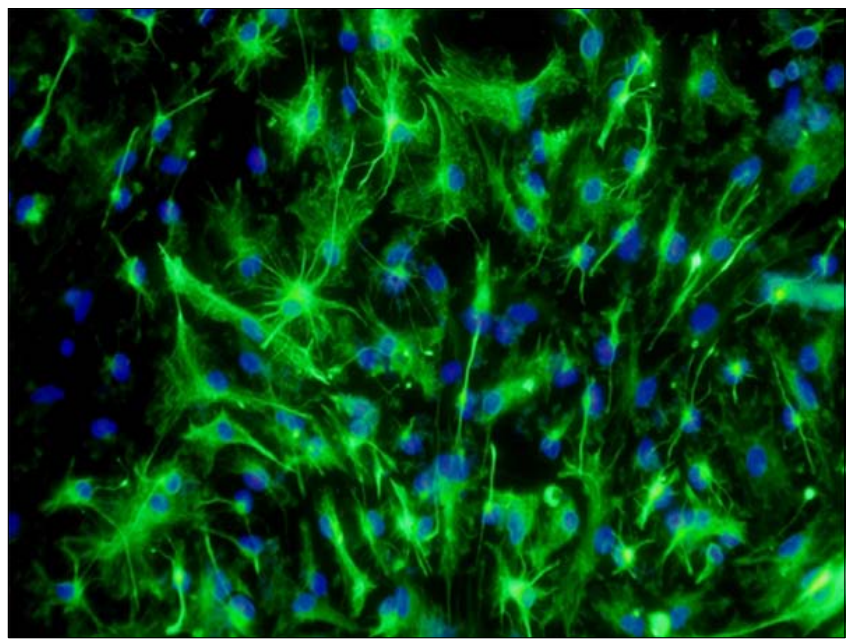

Astrocyte (GFAP immunocytochemistry)

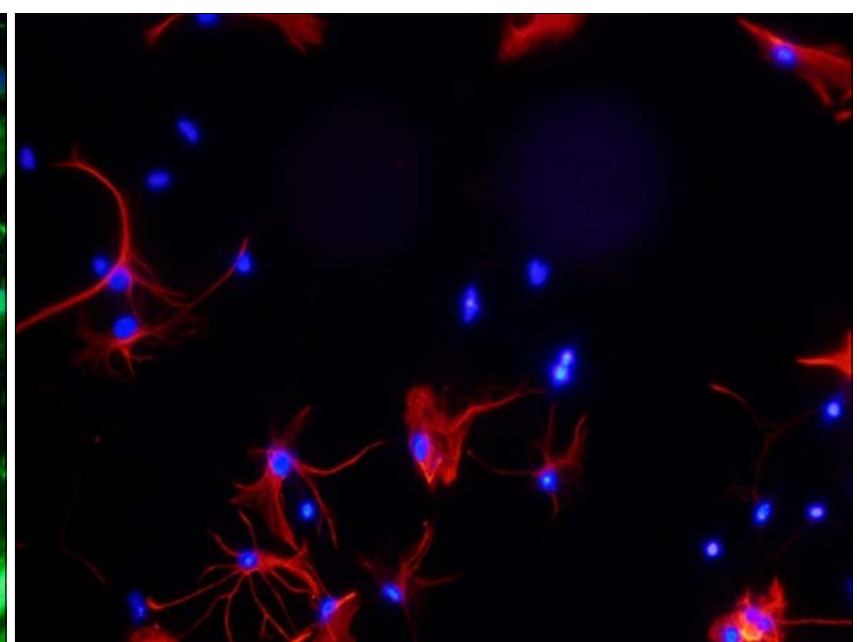

Neuron ( $\beta$-tubulin III immunocytochemistry)

Fig. 6. Neural Stem Cell Differentiation and immunocytochemistry with GFAP and $\beta$-tubulin III antibody.

Table 2. Neural Stem Cells Differentiation to neurons and astrocytes

\begin{tabular}{cc}
\hline$\beta$-tubulin III & GFAP \\
\hline $11.84 \% \pm 3.98$ & $84.25 \% \pm 5.62$ \\
\hline
\end{tabular}

were significantly decreased in comparison with the sham group. Also, the group received Mesenchymal stem cells and differentiated neural stem cells without astrocytes had the least ischemic area among the cell therapy groups (40.264 $\mathrm{mm}^{3} \pm 6.12$ ) that shows it could be more effective than the other methods (Fig. 9 and 10).

\section{Caspase 3 Activity Assay}

Some stem cells are capable of reducing apoptosis by down regulating some apoptotic genes such as caspase 3 (14). Caspase 3 activity was assessed by spectrophotometer at $405 \mathrm{~nm}$. The higher absorbance value revealed the higher Caspase 3activity and as a result the higher incidence of apoptosis. The result indicates that the group which received Mesenchymal stem cells and differentiated neural stem cells without astrocytes had the least amount of Caspase 3 activity between the rests of the groups and as a result the lowest amount of apoptosis $(0.215 \pm 0.04)$ (Fig. 11). 

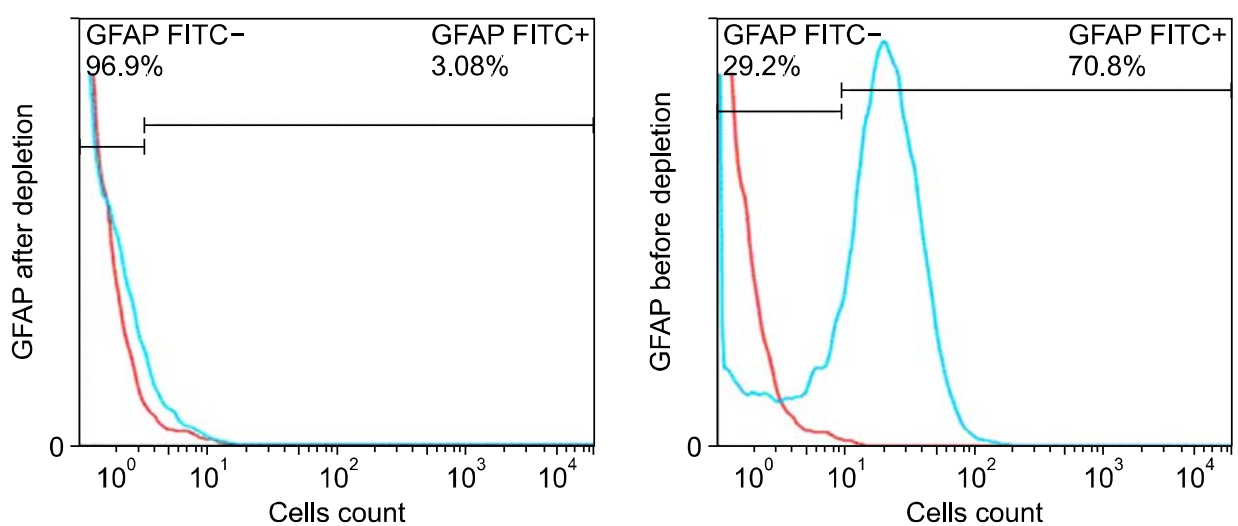

Flowcytometry for GFAP positive cells (Astrocytes) before and after depletion

Fig. 7. Flow cytometry for assessing depletion of astrocytes. The blue line is the GFAP positive cells.

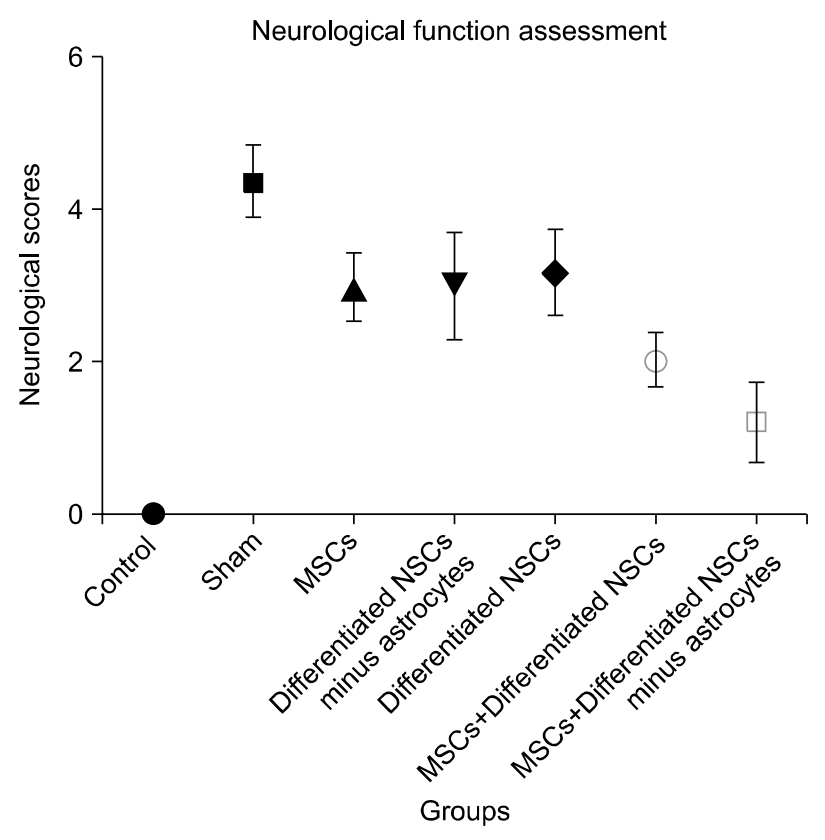

Fig. 8. Neurological scores in 28 days. The data was analyzed with One-way ANOVA and the $p$ value is less than 0.05 . The data between groups was analyzed with Tukey's multiple comparison tests.

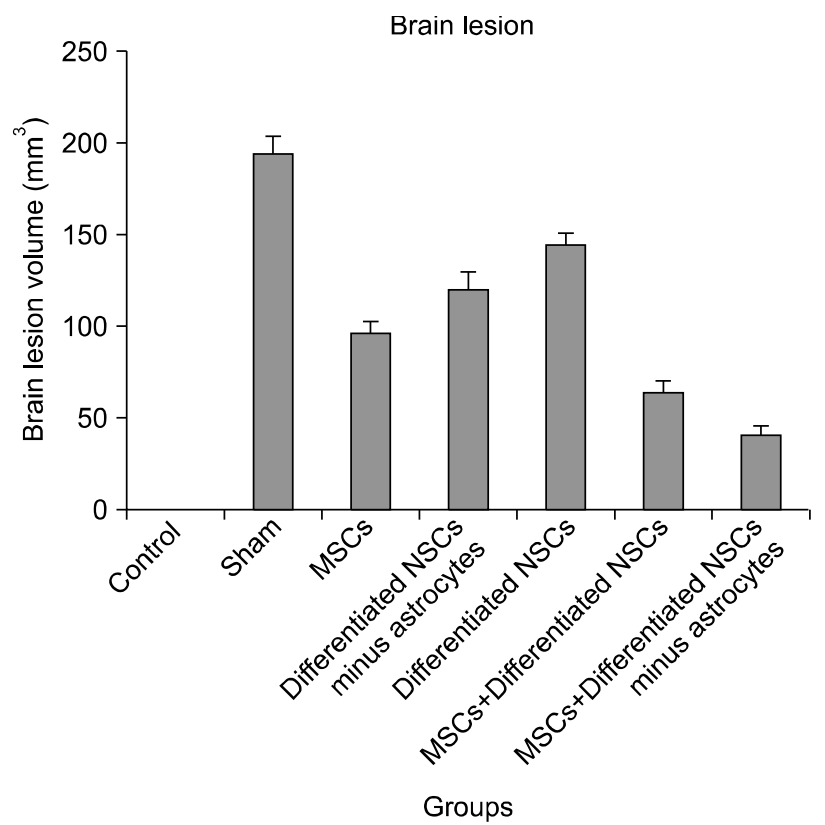

Fig. 9. H\&E staining and ischemic area volume. The data was analyzed with One-way ANOVA and the $p$ value is less than 0.05 . The data between groups was analyzed with Tukey's multiple comparison tests.

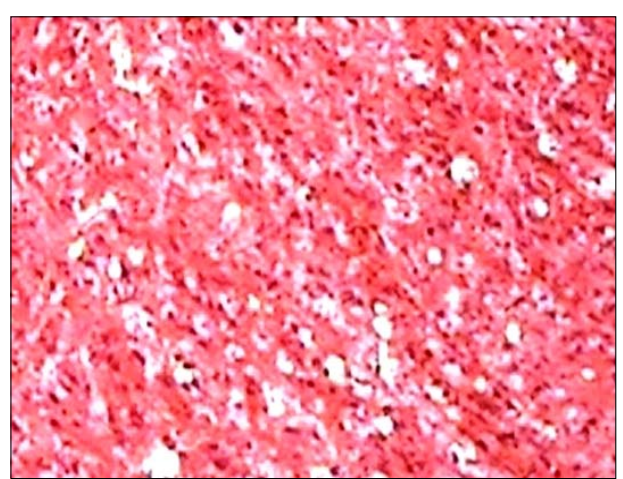

Normal tissue of brain

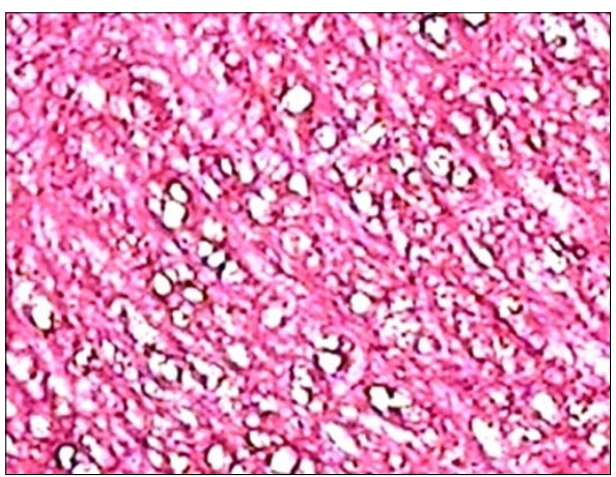

Infarcted area in brain
Fig. 10. $\mathrm{H} \& E$ staining for brain tissue. 


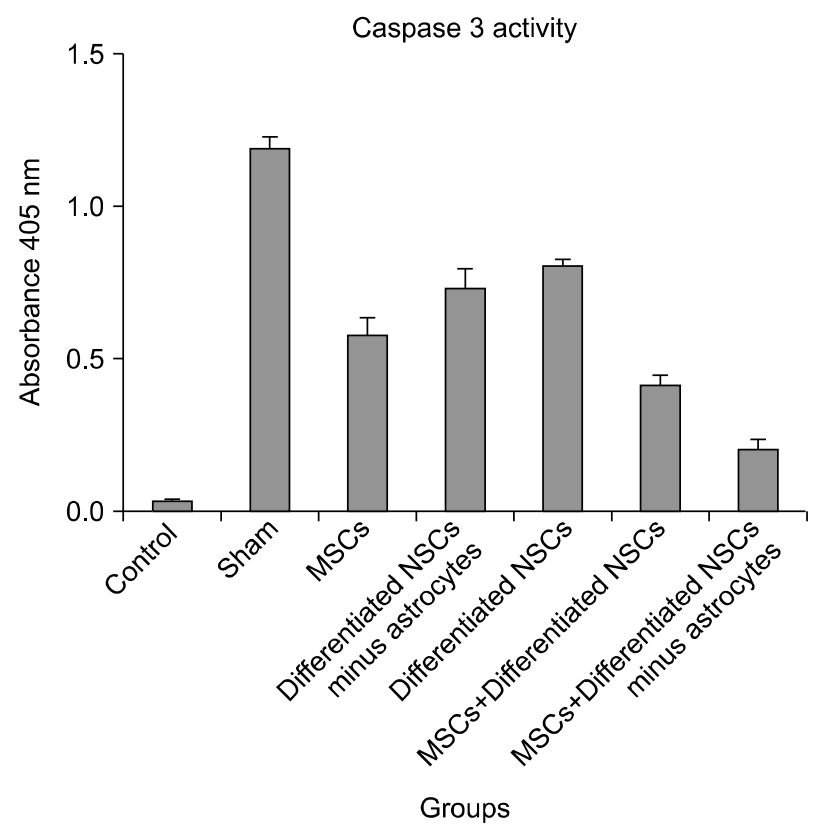

Fig. 11. Caspase 3 activity. The data was analyzed with One-way ANOVA and the $p$ value is less than 0.05. The data between groups was analyzed with Tukey's multiple comparison tests.

\section{Discussion}

In this study we have presented a novel cell therapy method for almost treating stroke with Mesenchymal stem cells and differentiated neural stem cells with astrocytes depletion.

We have designed different cell therapy method according to different characteristics of Mesenchymal stem cells and differentiated neural stem cells and according the results the combination cell therapy with MSCs and differentiated NSCs without astrocytes could improve neurological function and also reduce the brain lesion volume and apoptosis after brain stroke.

Mesenchymal stem cells have been shown suppress T-cell activation and proliferation and also reduce T-cells response indirectly by suppression of CD 34+ progenitor cell differentiation (14, 17-19). Some studies demonstrated that Mesenchymal stem cells are capable to have anti-inflammatory effects and secret some cytokines such as interleukin 10 (IL-10) and IL-6 according to their microenvironment and some pro-inflammatory cytokines including TNF- $\alpha$, IFN- $\lambda$ and IL- $\beta$ are potential to induce MSC anti-inflammatory effects (20-22). Cheng et al. in 2015 have shown that Mesenchymal stem cells transplantation could improve neurological function after stroke by their ability of attenuating inflammatory factors and also modulating TGF- $\beta$ (23). Calio et al. in 2014 Mesen- chymal stem cells transplantation could protect the brain tissue against stress oxidative and diminish apoptosis after stroke (24). As previous studies and our results indicate, the Mesenchymal stem cells could make less volume infarct, better neurological outcomes and less apoptosis especially in acute phase of stroke. In all groups which treated with Mesenchymal stem cells alone or with other cells, neurological recovery and decreasing of apoptosis could be observed.

Neural stem cells are a type of stem cells exists mostly in subventricular zone (SVZ) and dentate gyrus (DG), they are able to migrate to degenerating area and regenerate the damaged zone by anti-inflammatory effects and differentiation to three neural lineages containing neurons, oligodendrocytes and astrocytes (25-29). Despite of mentioned positive points of neural stem cells, they promote astrocytosis (30) and it might be an obstacle for reaching an optimum effect of neural stem cells transplantation. Stroke induces a series of changes in molecular and cellular aspects in brain tissue such as increasing morphology changes, cellular proliferation and genes expressions (31-34). The expression of GFAP would be increased in stroke which leads to astrocytosis and formation of glial scares that could surround the ischemic zone and inhibit regeneration and endogenous neural stem cells migration (35-39). Our results illustrates that the groups which received differentiated neural stem cells had better outcome and less apoptosis; however by omitting the astrocyte the outcome would be promoted and apoptosis would be diminished.

According to all above, we designed an experiment to define the effects of depleting astrocyte and a new method by combining differentiated neural stem cells and Mesenchymal stem cells for treating brain stroke. As our result shows depleting the astrocytes might have positive effects on recovering after stroke and it could be developed when the Mesenchymal stem cells were injected systemically.

\section{Potential conflict of interest}

The authors have no conflicting financial interest.

\section{References}

1. Wu D. Neuroprotection in experimental stroke with targeted neurotrophins. NeuroRx 2005;2:120-128

2. Broderick JP, William M. Feinberg Lecture: stroke therapy in the year 2025: burden, breakthroughs, and barriers to progress. Stroke 2004;35:205-211

3. Muir KW, Tyrrell P, Sattar N, Warburton E. Inflammation and ischaemic stroke. Curr Opin Neurol 2007;20:334-342

4. Dirnagl U, Iadecola C, Moskowitz MA. Pathobiology of is- 
chaemic stroke: an integrated view. Trends Neurosci 1999; 22:391-397

5. Zhu Y, Yang GY, Ahlemeyer B, Pang L, Che XM, Culmsee C, Klumpp S, Krieglstein J. Transforming growth factor-beta 1 increases bad phosphorylation and protects neurons against damage. J Neurosci 2002;22:3898-3909

6. Spera PA, Ellison JA, Feuerstein GZ, Barone FC. IL-10 reduces rat brain injury following focal stroke. Neurosci Lett 1998;251:189-192

7. Lakhan SE, Kirchgessner A, Hofer M. Inflammatory mechanisms in ischemic stroke: therapeutic approaches. J Transl Med 2009;7:97

8. Swanson RA, Ying W, Kauppinen TM. Astrocyte influences on ischemic neuronal death. Curr Mol Med 2004;4:193-205

9. Ginsberg MD. Cerebrovascular disease: pathophysiology, diagnosis, and management. Blackwell Science, Bogousslavsky J. Malden, UK: Blackwell Science; 1998:193-204

10. Furlan AJ, Katzan IL, Caplan LR. Thrombolytic therapy in acute ischemic stroke. Curr Treat Options Cardiovasc Med 2003;5:171-180

11. Hirouchi M, Ukai Y. Current state on development of neuroprotective agents for cerebral ischemia. Nihon Yakurigaku Zasshi 2002;120:107-113

12. Rehman J, Traktuev D, Li J, Merfeld-Clauss S, TemmGrove CJ, Bovenkerk JE, Pell CL, Johnstone BH, Considine RV, March KL. Secretion of angiogenic and antiapoptotic factors by human adipose stromal cells. Circulation 2004; 109:1292-1298

13. Chang DJ, Oh SH, Lee N, Choi C, Jeon I, Kim HS, Shin DA, Lee SE, Kim D, Song J. Contralaterally transplanted human embryonic stem cell-derived neural precursor cells (ENStem-A) migrate and improve brain functions in stroke-damaged rats. Exp Mol Med 2013;45:e53

14. Jiang XX, Zhang Y, Liu B, Zhang SX, Wu Y, Yu XD, Mao N. Human mesenchymal stem cells inhibit differentiation and function of monocyte-derived dendritic cells. Blood 2005;105:4120-4126

15. Koizumi J, Yoshida Y, Nakazawa T, Ooneda G. Experimental studies of ischemic brain edema: 1. A new experimental model of cerebral embolism in rats in which recirculation can be introduced in the ischemic area. Jpn J Stroke 1986;8:1-8

16. Longa EZ, Weinstein PR, Carlson S, Cummins R. Reversible middle cerebral artery occlusion without craniectomy in rats. Stroke 1989;20:84-91

17. Di Nicola M, Carlo-Stella C, Magni M, Milanesi M, Longoni PD, Matteucci P, Grisanti S, Gianni AM. Human bone marrow stromal cells suppress T-lymphocyte proliferation induced by cellular or nonspecific mitogenic stimuli. Blood 2002;99:3838-3843

18. Krampera M, Glennie S, Dyson J, Scott D, Laylor R, Simpson E, Dazzi F. Bone marrow mesenchymal stem cells inhibit the response of naive and memory antigen-specific T cells to their cognate peptide. Blood 2003;101:3722-3729

19. Ivanova-Todorova E, Bochev I, Mourdjeva M, Dimitrov R, Bukarev D, Kyurkchiev S, Tivchev P, Altunkova I, Kyurkchiev
DS. Adipose tissue-derived mesenchymal stem cells are more potent suppressors of dendritic cells differentiation compared to bone marrow-derived mesenchymal stem cells. Immunol Lett 2009;126:37-42

20. DelaRosa O, Dalemans W, Lombardo E. Mesenchymal stem cells as therapeutic agents of inflammatory and autoimmune diseases. Curr Opin Biotechnol 2012;23:978-983

21. Ma S, Xie N, Li W, Yuan B, Shi Y, Wang Y. Immunobiology of mesenchymal stem cells. Cell Death Differ 2014;21: 216-225

22. Shi Y, Hu G, Su J, Li W, Chen Q, Shou P, Xu C, Chen X, Huang Y, Zhu Z, Huang X, Han X, Xie N, Ren G. Mesenchymal stem cells: a new strategy for immunosuppression and tissue repair. Cell Res 2010;20:510-518

23. Cheng Q, Zhang Z, Zhang S, Yang H, Zhang X, Pan J, Weng L, Sha D, Zhu M, Hu X, Xu Y. Human umbilical cord mesenchymal stem cells protect against ischemic brain injury in mouse by regulating peripheral immunoinflammation. Brain Res 2015;1594:293-304

24. Calió ML, Marinho DS, Ko GM, Ribeiro RR, Carbonel AF, Oyama LM, Ormanji M, Guirao TP, Calió PL, Reis LA, Simões Mde J, Lisbôa-Nascimento T, Ferreira AT, Bertoncini CR. Transplantation of bone marrow mesenchymal stem cells decreases oxidative stress, apoptosis, and hippocampal damage in brain of a spontaneous stroke model. Free Radic Biol Med 2014;70:141-154

25. Eriksson PS, Perfilieva E, Björk-Eriksson T, Alborn AM, Nordborg C, Peterson DA, Gage FH. Neurogenesis in the adult human hippocampus. Nat Med 1998;4:1313-1317

26. Curtis MA, Kam M, Nannmark U, Anderson MF, Axell MZ, Wikkelso C, Holtås S, van Roon-Mom WM, BjörkEriksson T, Nordborg C, Frisén J, Dragunow M, Faull RL, Eriksson PS. Human neuroblasts migrate to the olfactory bulb via a lateral ventricular extension. Science 2007;315: 1243-1249

27. Kornblum HI, Geschwind DH. Molecular markers in CNS stem cell research: hitting a moving target. Nat Rev Neurosci 2001;2:843-846

28. Bull ND, Bartlett PF. The adult mouse hippocampal progenitor is neurogenic but not a stem cell. J Neurosci 2005; 25:10815-10821

29. Taupin P. The therapeutic potential of adult neural stem cells. Curr Opin Mol Ther 2006;8:225-231

30. Batrakova EV, Gendelman HE, Kabanov AV. Cell-mediated drug delivery. Expert Opin Drug Deliv 2011;8:415-433

31. Ding S, Wang T, Cui W, Haydon PG. Photothrombosis ischemia stimulates a sustained astrocytic $\mathrm{Ca}^{2+}$ signaling in vivo. Glia 2009;57:767-776

32. Li H, Zhang N, Sun G, Ding S. Inhibition of the group I mGluRs reduces acute brain damage and improves longterm histological outcomes after photothrombosis-induced ischaemia. ASN Neuro 2013;5:195-207

33. Panickar KS, Norenberg MD. Astrocytes in cerebral ischemic injury: morphological and general considerations. Glia 2005;50:287-298

34. Zamanian JL, Xu L, Foo LC, Nouri N, Zhou L, Giffard 
RG, Barres BA. Genomic analysis of reactive astrogliosis. J Neurosci 2012;32:6391-6410

35. Haupt C, Witte OW, Frahm C. Up-regulation of Connexin43 in the glial scar following photothrombotic ischemic injury. Mol Cell Neurosci 2007;35:89-99

36. Hayakawa K, Nakano T, Irie K, Higuchi S, Fujioka M, Orito K, Iwasaki K, Jin G, Lo EH, Mishima K, Fujiwara $M$. Inhibition of reactive astrocytes with fluorocitrate retards neurovascular remodeling and recovery after focal cerebral ischemia in mice. J Cereb Blood Flow Metab 2010; 30:871-882
37. Barreto GE, Sun X, Xu L, Giffard RG. Astrocyte proliferation following stroke in the mouse depends on distance from the infarct. PLoS One 2011;6:e27881

38. Bao Y, Qin L, Kim E, Bhosle S, Guo H, Febbraio M, Haskew-Layton RE, Ratan R, Cho S. CD36 is involved in astrocyte activation and astroglial scar formation. J Cereb Blood Flow Metab 2012;32:1567-1577

39. Shimada IS, Borders A, Aronshtam A, Spees JL. Proliferating reactive astrocytes are regulated by Notch- 1 in the peri-infarct area after stroke. Stroke 2011;42:3231-3237 